\title{
EU climate targets under fire
}

\section{Critics fear that Europe's proposed energy goals and emissions cuts are too soft.}

\section{BY QUIRIN SCHIERMEIER}

$\mathrm{J}$ osé Manuel Barroso wore a winning smile as he took to the stage in Brussels last week to announce a plan intended to shape Europe's low-carbon energy future and revitalize the stalling international climate debate. But scientists warn that the European Commission's proposal is at the low end of what is needed to curb climate change and might burden the next generation with soaring costs.

Europe is to cut its greenhouse-gas emissions to $40 \%$ below 1990 levels by 2030 , according to the commission's proposed energy and climate framework. This would double the previous 2020 ambitions of the European Union (EU), argues commission president Barroso (see 'Slow decline'). But with emissions already almost 20\% down compared with 1990 levels - thanks largely to the collapse of former Eastern bloc industries and the global economic crisis - little additional effort will be required to meet that goal, say critics. And because the commission wants to replace binding national targets for renewable energy with a soft EU-wide aspirational goal, many feel that the package is regressive rather than a leap ahead in climate policies.

"A sole 40\% reduction target is neither in line with what is economically feasible nor with what the science says is needed to avoid dangerous climate change," says Rebecca Harms, co-chair of the Green group in the European Parliament. The Parliament must still approve the package in a plenary vote expected next month. If it does, the measures could become binding EU legislation before the end of the year.

Although achievable at modest economic cost, the proposed $40 \%$ target might not be enough to meet the EU's longer-term ambitions of reducing emissions by at least $80 \%$ by 2050 , according to a multi-model study of energy transformation pathways published last month (B. Knopf et al. Clim. Change Econ. 4 (suppl. 1), 1340001; 2013).

"By 2030 , it is possible to achieve a $40 \%$ emission reduction using existing technologies," says Brigitte Knopf, an energy specialist at the Potsdam Institute for Climate Impact Research in Germany, who led the study. "But our models suggest that costs might rise sharply after 2040 if we do not incentivize technological innovation by clearly pricing greenhouse-gas emissions. Otherwise, the last step, from $70 \%$ or so to almost full decarbonization of the entire economy, could be hard to achieve."

The study finds that Europe can accomplish

\section{SLOW DECLINE}

The European Commission has proposed cutting EU greenhouse-gas emissions by $40 \%$ of 1990 levels by 2030

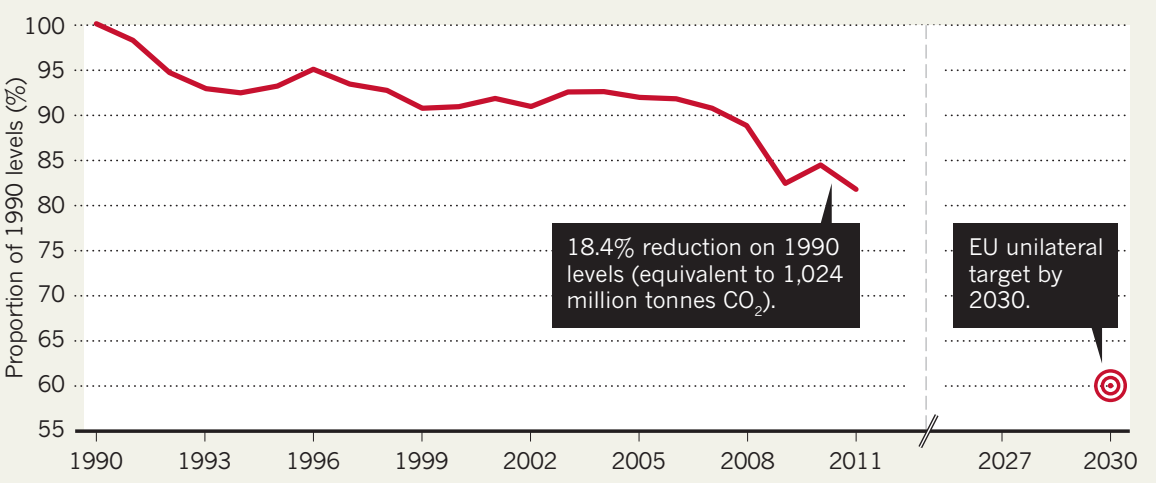

its climate ambitions without relying on controversial carbon capture and storage technology. However, substantial progress across a range of other energy technologies, such as organic solar cells or even nuclear fusion, will be needed to meet the EU's long-term goal while keeping costs in check, Knopf says.

Obstacles on the road to a low-carbon future include unresolved problems with both energy storage and long-distance power transmission, says Claudia Kemfert, a climate and energy economist at the German Institute for Economic Research in Berlin. Future efforts, she says, must also include the development of low-carbon fuels and research into possible new energy sources, such as ocean energy.

The proposed framework leaves it to EU member countries to decide how to achieve their national emissions-reduction targets in the most cost-efficient way.

"It feels as if
political elites
are suffering the
climate debate
rather than
engaging in it."

Some fear that this will limit the speed of transition to a renewable-energy-based economy and thwart the creation of hundreds of thousands of 'green' jobs.

"The science shows that a renewable energy target would go a long way in creating jobs and economic growth in Europe without increasing the costs of the energy system," says Jacopo Moccia, a policy director at the European Wind Energy Association in Brussels.

Indeed, a leaked internal impact assessment by the European Commission finds that a robust 2030 renewable-energy target would create substantially more jobs and economic growth than will a sole greenhouse-gasemissions target as proposed last week.

Some EU governments share that view. In a letter sent to Brussels last month, ministers from eight countries - Austria, Belgium, Denmark, France, Germany, Ireland, Italy and Portugal - urged the commission not to abandon the successful system of mandatory national renewable targets. Firm targets, which are crucial to ensure cost-effective investments in energy systems, will, they argue, "lead to decreased dependency on energy imports and ... will pave the way for an efficient planning and expansion of the European grid".

Others - including the United Kingdom, Poland and the Czech Republic - oppose that view, arguing instead that EU member states need flexibility as they try to move towards a low-carbon economy.

Unlike Germany, which is phasing out the use of nuclear energy by 2022, the United Kingdom, France and other EU countries do see a viable nuclear future. Poland, which relies more heavily on electricity from coal-powered plants than any other EU country, would rather abstain from greenhouse-gas reduction obligations altogether.

Even so, Barroso is confident that Europe can take a leading role in the negotiation process towards a new global climate agreement at a United Nations conference in Paris next year. But critics fear that the climate discussion has passed its sell-by date.

"Back in 2008, climate change was a toppriority issue among world leaders," says Harms. "Six years on, it feels as if political elites are suffering the climate debate rather than engaging in it." - SEE EDITORIAL P.585 